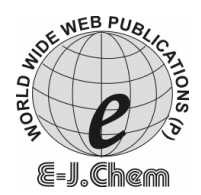

http://www.e-journals.net
ISSN: 0973-4945; CODEN ECJHAO

E-Journal of Chemistry

Vol. 5, No.4, pp. 792-796, October 2008

\title{
Chemical Properties of Groundwater in Bhiloda Taluka Region, North Gujarat, India
}

\author{
G.D. ACHARYA ${ }^{\S}$, M.V. HATHI ${ }^{\S}$, \\ ASHA D. PATEL and K.C. PARMAR \\ ${ }^{\S}$ Department of Chemistry, R.R. Mehta College of Science \& \\ C.L. Parikh College of Commerce, Palanpur- 385001 (INDIA) \\ Department of Chemistry \\ Hemchandracharya North Gujarat University Patan-384265 (INDIA) \\ drashapatel@yahoo.co.in
}

Received 8 January 2008; Accepted 5 March 2008

\begin{abstract}
Groundwater is one of the most useful water sources. Contamination of such water source is a big problem creating health hazards. In this present study we have collected groundwater samples from different places of Bhiloda taluka of Sabarkantha district (North Gujarat) India. These samples have been assessed on the basis of various qualitative parameters. The results of physicochemical study of water samples from 13 bore wells in Bhiloda taluka are presented. The water quality parameters such as; $\mathrm{pH}$, electrical conductivity (EC), total dissolved salts (TDS), calcium and magnesium, sodium, potassium, carbonate, bicarbonate, chloride, sulphate, fluoride, sodium adsorption ratio (SAR), residual sodium carbonate (RSC) and soluble sodium percentage ( SSP ) were estimated.
\end{abstract}

Keywords: Groundwater, Contamination, SSP, RSC, SAR, TDS,EC

\section{Introduction}

Quality of water is an important consideration in any appraisal of salinity or alkali conditions in an irrigated area. Nearly all irrigation water that have been used successfully for a long period have a conductivity value less than $2250 \mathrm{mmhos} / \mathrm{cm}$. Water of higher conductivity may be used with suitable amendments and precautions, but under normal conditions they are harmful to the soil structure and their continuous use will result in salinity hazard, with ultimate effect on plant growth. This deterioration of the soils is judged from the ratios of soluble sodium percentage (SSP), sodium adsorption ratio (SAR) and residual sodium carbonate (RSC). 


\section{Experimental}

All the thirteen water samples were examined for electrical conductivity, $\mathrm{pH}$ and the proportion of various cations and anions. The chemical analysis was carried out using following standard procedures. The results of chemical analysis of water samples are given in Table 1. The results show the different ratios to judge the quality of this water from irrigation view points.

\section{Materials and methods}

The groundwater samples were collected from 13 bore wells in selected stations of Bhiloda taluka region. The samples were collected as per the standard methods recommended by APHA $^{1}$. Before water sampling, all the double-stoppered polythene containers were cleaned and rinsed thoroughly with water samples to be analyzed. The physico-chemical analysis was done using the standard methods.

\section{Results and Discussion}

$p H$

The $\mathrm{pH}$ value ranges between 8.0 and 9.4. The lowest value is observed in Jayla and the highest in Reetoda villege (Table 1). It is observed that $76 \%$ of the water samples lie in the range of $6.5-8.5$ prescribed by Bureau of Indian Standards.

\section{Electrical conductivity (EC)}

Electrical conductivity is a useful tool to evaluate the purity of water maximum electrical conductivity is recorded in sunokh $(3342 \mu \mathrm{mhos} / \mathrm{cm})$ and the minimum EC at Jinava (231 $\mu \mathrm{mhos} / \mathrm{cm})$. The result indicates that almost all the water samples are within the permissible limits of $2250 \mu \mathrm{mhos} / \mathrm{cm}$ except at sampling locations $v i z$, Sunokh $(3442 \mu \mathrm{mhos} / \mathrm{cm})$, Madhtimba (2739 $\mu \mathrm{mhos} / \mathrm{cm})$, Padara (3304 $\mu \mathrm{mhos} / \mathrm{cm})$ and Jayla $(3281 \mu \mathrm{mhos} / \mathrm{cm})$.

\section{Total dissolved solid (TDS)}

The TDS of the water samples ranged from $145 \mathrm{mg} / \mathrm{L}$ to $1910 \mathrm{mg} / \mathrm{L}$. The ISI standard for dissolved solid is up to $500 \mathrm{mg} / \mathrm{L}$ and the maximum permissible quantity ${ }^{8}$ is $2000 \mathrm{mg} / \mathrm{L}$ (WHO, 1994). The TDS values of all the water samples of the selected places areunder permissible limit of $2000 \mathrm{mg} / \mathrm{L}$.

\section{$\mathrm{Ca}^{+2}$ and $\mathrm{Mg}^{+2}$ hardness}

$\mathrm{Ca}^{+2}$ and $\mathrm{Mg}^{+2}$ cause by far the greatest portion of the hardness occurring in natural waters. Hardness of the water is objectionable from the viewpoint of water use. The $\mathrm{Ca}^{+2}+\mathrm{Mg}^{+2}$ Values of the water samples from 3.1 to $12.3 \mathrm{meq} / \mathrm{L}$. The lowest value of $3.1 \mathrm{meq} / \mathrm{L}$ from sunokh where the highest value of $12.3 \mathrm{meq} / \mathrm{L}$ was recorded in water samples from kebava. The values of total hardness of $77 \%$ samples are within the permissible range. The highest desirable limit of total hardness is $6.0 \mathrm{meq} / \mathrm{L} \mathrm{(300} \mathrm{mg/L)} \mathrm{(ICMR} \mathrm{1975).}$

\section{Sodium}

Sodium content of the groundwaters of Bhiloda taluka ranges from $0.5 \mathrm{meq} / \mathrm{L}$ (Jinava) to $32.87 \mathrm{meq} / \mathrm{L}$ (Sunokh) (Table 1). About $61 \%$ of the water samples show sodium higher than the permissible limit of $50 \mathrm{ppm}(9 \mathrm{meq} / \mathrm{L})$ in irrigation water prescribed by BIS (1983). 


\section{Potassium}

In the present study of all the water samples have potassium higher than the permissible limit of $0.5 \mathrm{meq} / \mathrm{L}$ as prescribed by BIS and ranges from $0.00 \mathrm{meq} / \mathrm{L}$ (Jinava) to $0.03 \mathrm{meq} / \mathrm{L}$ (Bhatera).

\section{Bicarbonate}

The values of $\mathrm{HCO}_{3}{ }^{-}$in the water samples varied from 2.90 to $15.00 \mathrm{meq} / \mathrm{L}$ (Table 1 ). The lowest value of $2.90 \mathrm{meq} / \mathrm{L}$ was observed in the water sample obtained from Jinava where as the highest value of $15.00 \mathrm{meq} / \mathrm{L}$ was observed in Jayla Village. All the samples are far below than the permissible limit of $120 \mathrm{meq} / \mathrm{L}$.

\section{Chloride}

It is observed that around $53 \%$ of the samples have chlorides higher than the permissible limit of $10.0 \mathrm{meq} / \mathrm{L}$. The highest concentration of chlorides was recorded in padara $(19.5$ meqL) and the lowest at Bhatera $(1.00 \mathrm{meq} / \mathrm{L})$. High chloride content in groundwater can be attribute to lack of under ground drainage system and bad maintenance of environment around the sources.

\section{Fluoride}

Fluoride content of groundwater samples of the study areas ranges from 0.20 to $1.10 \mathrm{ppm}$. Maximum $^{7}$ allowable limit is $1.5 \mathrm{ppm}$ (WHO, 1984). It is under permissible limit. Small concentration of fluoride in drinking water has beneficial effect on human body. Low concentration of fluoride bellow $0.5 \mathrm{ppm}$ causes dental caries and higher concentration beyond $1.5 \mathrm{ppm}$ causes dental and skeletal fluorosis.

\section{Sulfates}

High sulfate contest of 3.0, 1.3 and $0.8 \mathrm{meq} / \mathrm{L}$ was recoded at Vijapur, Jayla and Khokhara respectively. The presence of high concentration of sulfates in the study area can be attributed the discharge of domestic sewage and littering of organic wastes in the region.

\section{Sodium adsorption ratio (SAR)}

The suitability of the well and bore well water samples was judged by determining the SAR value and they were categorized under different irrigation classes on the basis of salinity and alkalinity hazards. Sodium adsorption ratio (SAR) was computed by using values of watersoluble cation (Table 1). The SAR values varied from 0.37 to 26.40 . The data revealed that about $54 \%$ of the water samples of the taluka under study have low values $(<10.0)$.

\section{Residual sodium carbonates (RSC)}

Residual sodium carbonate (RSC) was computed by using values of water sodium $\left(\mathrm{CO}_{3}^{-2}\right.$ and $\left.\mathrm{HCO}_{3}^{-1}\right)$ and cations $\left(\mathrm{Ca}^{+2}+\mathrm{Mg}^{+2}\right)$ where the ionic concentration is in meq/L. The RSC values varied from -6.60 to 12.20 .

\section{Soluble sodium percentage (SSP)}

The soluble sodium percentage (SSP) values of the water samples of Bhiloda taluka ranged from 12.2 to 91.4 . The lowest value of 12.2 per cent was observed in Jinava whereas the highest values of 94.4 per cent was recorded in a water sample from Sunokh Village further the data revealed that about 61.53 per cent of the water samples have high values $(>60)$ of SSP. 
Table 1. Physico - chemical characteristics of groundwater in Bhiloda taluka (N. Gujarat)

\begin{tabular}{|c|c|c|c|c|c|c|c|c|c|c|c|c|c|c|}
\hline S.No. & $\mathrm{pH}$ & $\begin{array}{c}\text { EC } \mu \text { mhos/ } \\
\mathrm{cm}\end{array}$ & $\begin{array}{l}\text { TDS } \\
\mathrm{mg} / \mathrm{L} \\
\end{array}$ & $\begin{array}{c}\mathrm{Ca}^{+2}+\mathrm{Mg}^{+} \\
\text {meq } / \mathrm{L}\end{array}$ & $\begin{array}{c}{ }^{2} \mathrm{Na}^{+} \\
\mathrm{meq} / \mathrm{L}_{1}\end{array}$ & $\begin{array}{c}\mathrm{K}^{+} \\
\mathrm{meq} / \mathrm{L}\end{array}$ & $\begin{array}{l}\mathrm{CO}_{3}^{-2} \\
\mathrm{meq} / \mathrm{L} \\
\end{array}$ & $\begin{array}{l}\mathrm{HCO}_{3}^{-1} \\
\mathrm{meq} / \mathrm{L}\end{array}$ & $\begin{array}{c}\mathrm{Cl}^{-} \\
\mathrm{meq} / \mathrm{L}\end{array}$ & $\begin{array}{c}\mathrm{F}^{-} \\
\mathrm{ppm}\end{array}$ & $\begin{array}{l}\mathrm{SO}_{4}^{-2} \\
\mathrm{meq} / \mathrm{L}\end{array}$ & $\begin{array}{c}\mathrm{SAR} \\
\mathrm{meq} / \mathrm{L}\end{array}$ & $\mathrm{RSC}$ & $\begin{array}{c}\text { SSP } \\
\%\end{array}$ \\
\hline 1 & 8.62 & 1023 & 560 & 5.8 & 5.08 & 0.03 & 1.3 & 6.8 & 2.8 & 0.30 & 0.0 & 2.98 & 2.3 & 46.52 \\
\hline 2 & 9.20 & 3442 & 1910 & 3.1 & 32.87 & 0.01 & 1.1 & 14.2 & 17.5 & 0.34 & 2.6 & 26.40 & 12.2 & 91.36 \\
\hline 3 & 9.40 & 1945 & 1040 & 4.8 & 15.56 & 0.01 & 1.4 & 6.3 & 10.5 & 0.44 & 0.8 & 10.04 & 2.9 & 76.39 \\
\hline 4 & 9.00 & 2739 & 1456 & 4.2 & 26.30 & 0.00 & 1.6 & 10.7 & 14.0 & 0.24 & 1.0 & 18.15 & 8.1 & 86.23 \\
\hline 5 & 8.41 & 2006 & 1078 & 7.9 & 12.00 & 0.02 & 1.2 & 6.6 & 11.0 & 0.24 & 3.0 & 6.04 & -0.1 & 60.24 \\
\hline 6 & 8.60 & 3304 & 1715 & 6.7 & 24.87 & 0.02 & 1.4 & 11.9 & 19.5 & 0.26 & 0.0 & 13.59 & 6.6 & 78.73 \\
\hline 7 & 8.80 & 231 & 145 & 3.6 & 0.50 & 0.00 & 0.6 & 2.9 & 3.6 & 0.30 & 0.0 & 0.37 & -0.1 & 12.19 \\
\hline 8 & 8.65 & 1189 & 660 & 3.8 & 9.78 & 0.01 & 1.0 & 9.6 & 2.0 & 1.10 & 0.0 & 7.10 & 6.8 & 71.96 \\
\hline 9 & 8.68 & 614 & 350 & 4.1 & 4.50 & 0.03 & 1.6 & 4.9 & 1.0 & 0.22 & 0.0 & 3.14 & 2.4 & 52.14 \\
\hline 10 & 8.80 & 1620 & 940 & 12.3 & 7.50 & 0.03 & 0.9 & 4.8 & 8.5 & 0.20 & 0.5 & 3.02 & -6.6 & 37.82 \\
\hline 11 & 8.00 & 3281 & 1880 & 4.6 & 29.78 & 0.02 & 1.2 & 15.0 & 16.0 & 0.52 & 1.3 & 19.64 & 11.6 & 86.57 \\
\hline 12 & 8.45 & 1831 & 1070 & 3.5 & 15.30 & 0.02 & 1.3 & 6.3 & 11.0 & 0.39 & 0.8 & 11.57 & 4.1 & 81.30 \\
\hline 13 & 8.75 & 640 & 410 & 3.2 & 3.39 & 0.01 & 1.1 & 4.1 & 2.2 & 0.56 & 0.0 & 2.68 & 2.0 & 51.36 \\
\hline
\end{tabular}




\section{References}

1. APHA, Standard methods for the examination of water and waste water; Washington DC, USA, 1995.

2 Praharaj A K, Mohanta B K and Manda N K, Poll Res., 2004, 23(2), 399-402.

3. Madhavi A, Poll Res., 2005, 24(2), 395-400.

4. Prajapati J R and Raol B V, Poll Res., 2004, 23(1), 165-168.

5. Patel K P, Poll Res., 2003, 22(2), 241-245.

6. Mitra A and Gupta S K, J Indian Soc Soil Sci., 1999, 47, 99-105.

7. WHO, Guidelines for drinking water quality I, Geneva, 1984.

8. WHO, International Standards for drinking water WHO, Geneva, 1994. 


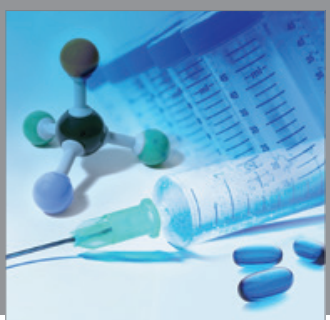

International Journal of

Medicinal Chemistry

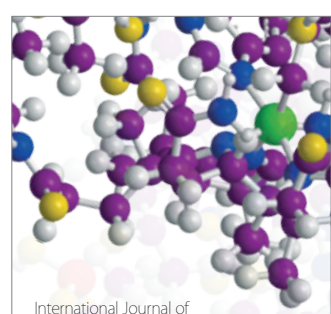

Carbohydrate Chemistry

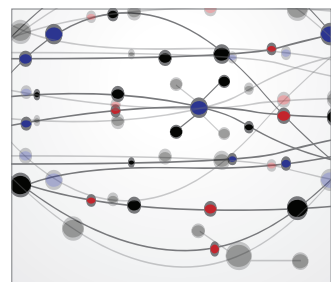

The Scientific World Journal
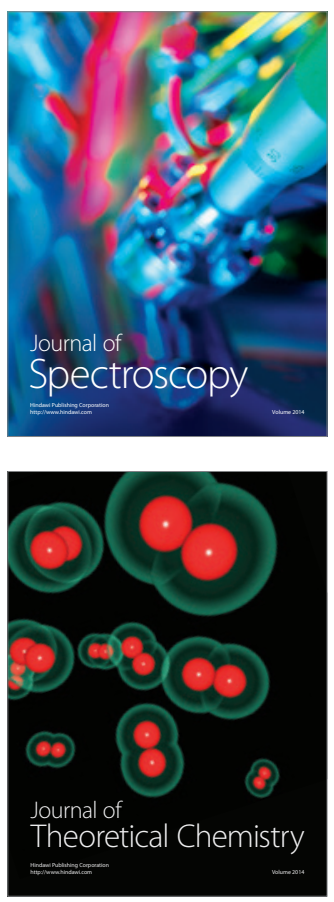
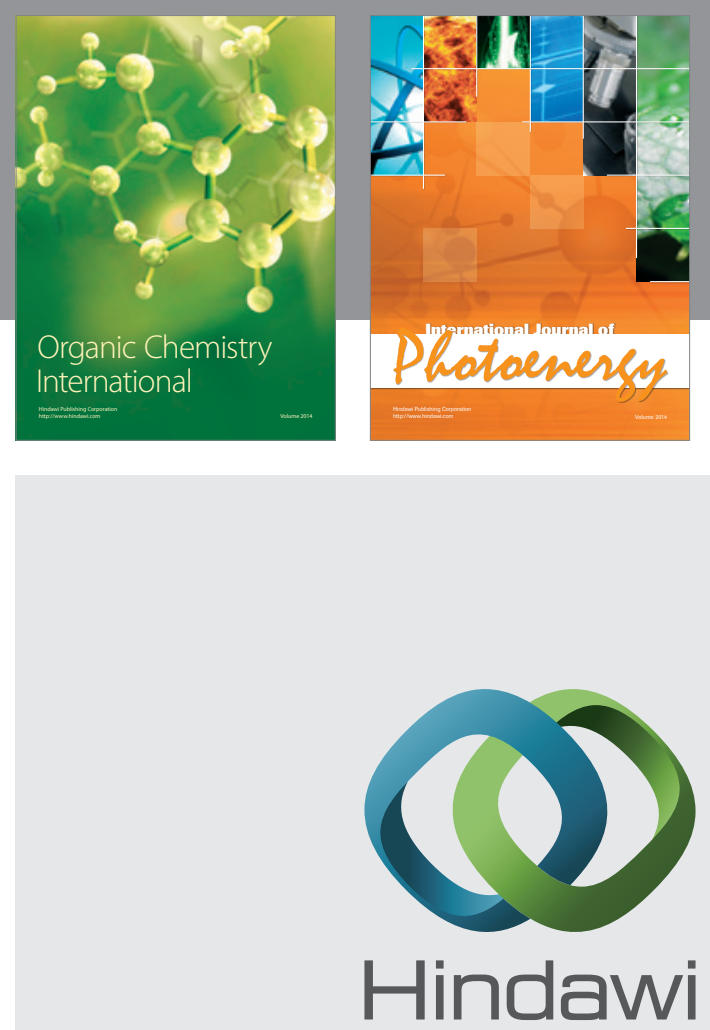

Submit your manuscripts at

http://www.hindawi.com
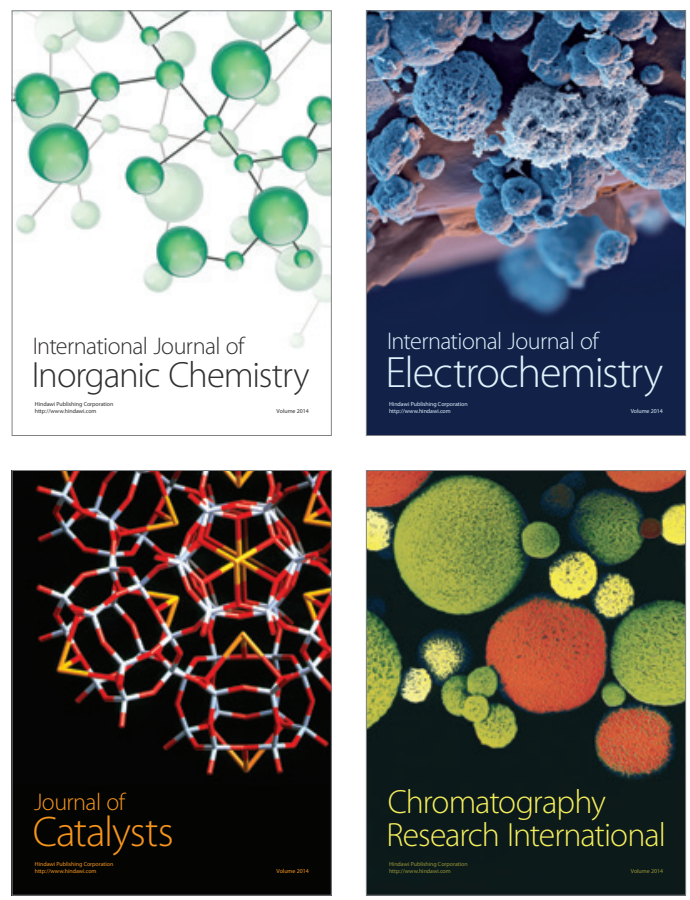
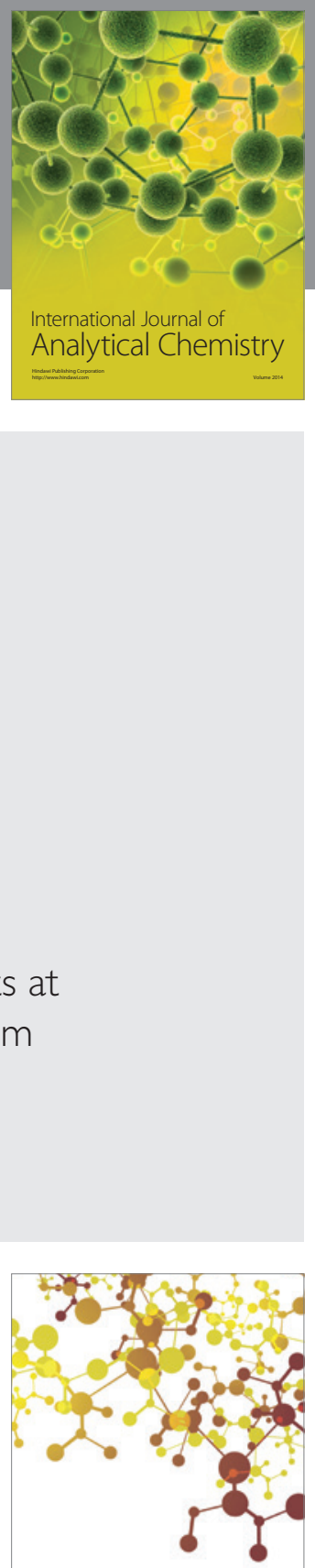

Journal of

Applied Chemistry
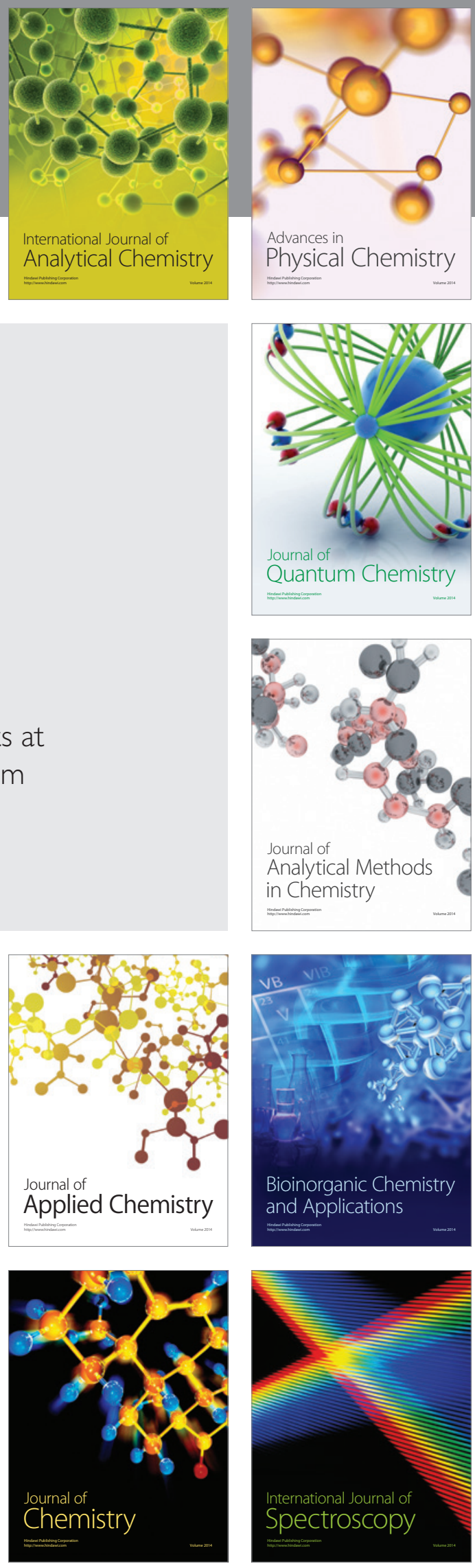